\title{
The ovarian and uterine responses of Baixadeiro mares to prostaglandin synchronization during the dry and rainy seasons
}

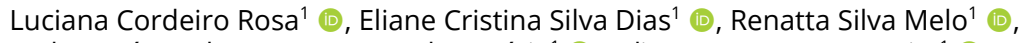

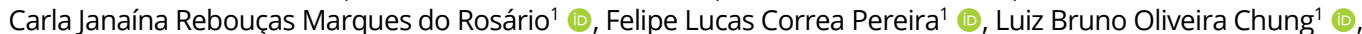

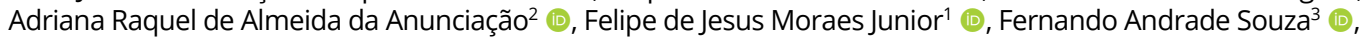 \\ Ricardo de Macêdo Chaves ${ }^{1 *}$ (1) \\ ${ }^{1}$ Laboratório de Reprodução Animal, Universidade Estadual do Maranhão, São Luís, MA, Brasil \\ ${ }^{2}$ Faculdade de Medicina Veterinária e Zootecnia, Universidade de São Paulo, São Paulo, SP, Brasil e Faculdade Maurício de \\ Nassau, São Luís, Brasil. \\ ${ }^{3}$ Laboratório de Reprodução Animal, Universidade Federal do Paraná, Curitiba, PR, Brasil
}

How to cite: Rosa LC, Dias ECS, Melo RS, Rosário CJRM, Pereira FLC, Chung LBO, Anunciação ARA, Moraes Junior FJ, Souza FA, Chaves RM. The ovarian and uterine responses of Baixadeiro mares to prostaglandin synchronization during the dry and rainy seasons. Anim Reprod. 2022;19(1): e253226. DOI: https://doi.org/ 10.1590/1984-3143-AR2020-0050

\begin{abstract}
This study aimed to evaluate the effect of synchronization with prostaglandin F2a in Baixadeiro mares during the rainy and dry seasons. Fourteen mares were synchronized by administering two doses of $1 \mathrm{~mL}$ prostaglandin PGF 2a and monitored by rectal palpation and ultrasound for the assessment of follicular development and uterine echotexture. Of this total, nine mares allowed the collection of blood, in which the blood was collected by venipuncture of the jugular vein to determine progesterone (P4) by ELISA. Mares showed no differences $(P>0.05)$ in weight, body score condition (BSC), tone, uterine edema, frequency of ovulation, synchronization interval, estrus, and the total number of follicles between periods. However, there was a difference in large increased follicle diameter $(P<0.05)$ during the dry season. The average concentrations of P4 in mares differed $(P<0.05)$ between the pre- and post-ovulatory phases for both seasons and after ovulation, with higher concentrations in the rainy season. Furthermore, statistical differences in daily light $(P<0.05)$ were observed between the dry and rainy periods. Thus, we conclude that mares from the genetic grouping Baixadeiro showed no reproductive seasonality, though there was a difference in luminosity between the rainy and dry seasons. The treatment with two doses of PGF $2 a$ was effective in synchronizing the mares, promoting the return of estrus in the dry and rainy periods. The mares remaining cyclically active throughout the year provided there were appropriate forage availability and quality levels to allow for normal values of body weight and condition.
\end{abstract}

Keywords: estrus, follicular development, Baixadeiro mares.

\section{Introduction}

The "Baixadeiro" horse consists of a breed of native horses, typical of the Baixada Maranhense region, bred in the wilderness and acknowledged for their rusticity, physical strength as workhorses and resistant to dwelling on vast flat areas of flooded fields during the rainy season and cracked soil in the dry period. This racial group is small, with a predominant light gray or chestnut coats resulting from crossbreeding breeds introduced from the Iberian Peninsula (Gazolla et al., 2009). They are also more resistant to local environmental conditions than other breeds (Serra, 2004).

*Corresponding author: rmchaves@hotmail.com

Received: July 12, 2021. Accepted: December 11, 2021.

Financial support: RMC, Funding acquisition, supervision. received funding for this research from Fundação de Amparo à Pesquisa e ao Desenvolvimento Científico e Tecnológico do Maranhão - FAPEMA. (Grant numbers ${ }^{\circ}$ 03629/13) and acknowledgement to Coordenação de Aperfeiçoamento de Pessoal de Nível Superior - CAPES.

Conflicts of interest: The authors have no conflict of interest to declare.

(c) (i) Copyright (c) The Author(s). This is an Open Access article distributed under the terms of the Creative Commons Attribution License, which permits unrestricted use, distribution, and reproduction in any medium, provided the original work is properly cited. 
Data on the origin, reproductive characteristics and calving time of this genetic grouping are not yet known. Reports from breeders indicate that mares can give birth throughout the year. However, these horses are generally classified as seasonal breeders, presenting several cycles throughout the reproductive season. Several factors can influence reproduction, such as those related to the immune system and environmental factors such as photoperiod and temperature, nutritional factors, and seasonality (Klein and Nelson, 1999; Nagy et al., 2000, Ferreira-Dias et al., 2005).

In mares the interovulatory interval lasts an average of 21 days, varying according to the duration of estrus, a wide variation due to differences in estrus length (Cuervo-Arango et al., 2015). The growth and development of follicles occur at this stage (Moura, 2012), resulting in the dominance of a single preovulatory follicle (Morel et al., 2010). This process ends in ovulation with the formation of the corpus luteum (Arruda et al., 2001), increasing progesterone's secretion, the hormone involved in maintaining ovarian activity (FerreiraDias et al., 2005). In high-latitude regions, during the anovulatory season, most mares maintain progesterone levels below $1 \mathrm{ng} / \mathrm{mL}$ (Ginther, 1990), the latter being an efficient way to check the mares' ovarian cyclicity and CL activity (Arruda et al., 2001).

Traits related to follicular development may vary between breeds and between animals from different regions (Valle et al., 2005), especially those close to the equator. Information on reproductive seasonality and ovarian activity is limited (Boeta et al., 2006). In equatorial areas, seasonality of main factors affecting the success of breeding, such as the peak of grass growth, may differ from temperate areas (Carranza et al., 2017).

Estrus synchronization in equine females is a biotechnique that presents some obstacles due to the characteristics physiological of the species, however it allows manipulating the estrous cycle and follow the follicular development until the detection of ovulation. The duration of the interval between ovulations in the equine species is approximately 22 days, during which two-thirds are constituted by the luteal phase (diestrus) and one third by the follicular phase (estrus) (McKinnon and Voss, 1992).

The PGF $2 a$ starts the regression of the corpus luteum, approximately 14 days after ovulation, in the absence of pregnancy, in large domestic species (Stabenfeldt and Edqvist, 1996). Thus, synchronization protocols that use this hormone aim to induce luteolysis of a corpus luteum and recruit a new follicular wave (Haetinger et al., 2008). The aim of this study was to evaluate the effect of synchronization with prostaglandin F2a in Baixadeiro mares during the rainy and dry seasons.

\section{Materials and methods}

\section{Location and trial period}

The experiment was carried out in two stages, the first during the rainy (RS - February) and dry (DS - July) 2015 season. The averages for the entire period of rainfall was $0.319 \pm 1.71 \mathrm{~mm}$, temperature was of $26.99 \pm 2.33^{\circ} \mathrm{C}$ and humidity was $84.50 \pm 10.00 \%$.

\section{Experimental grouping}

The experiment involved fourteen mares whose mean age and mean height were, respectively, $6.35 \pm 1.21$ years and $128.43 \pm 5.74 \mathrm{~cm}$. They were originally free-ranged in the fields of the Baixada Maranhense region and introduced to the Experimental Farm of UEMA and included nulliparous, lactating and multiparous mares, all empty, evaluated by ultrasonography. From this total, nine mares were selected whose temperament and restraint allowed the blood to be collected for the hormonal assay. The animals were raised on pastures of native vegetation (Paratheria prostata, Paspalum virgatum, and Acrocera zizanoides; Serra, 2004), in paddocks of 0.5 ha and supplemented with commercial ration (Equimax® $12 \mathrm{MA}$ ). 
Measurements of live weight variations at 10-day intervals were recorded using equine weighing tapes and the body condition score (BCS), based on the Henneke et al., (1983) scale, considering the beginning, middle, and end of each step, to calculate the mean values per period.

\section{Synchronization}

In both wet and dry seasons, mares were synchronized with prostaglandin F2a (Sincrocioß) to complete the previous luteal phase and control ovulation time (Faria and Gradela, 2010). For this, two doses of $1 \mathrm{~mL}$ of PGF2a were used with an interval of 10 days. 72 hours after the second dose, the mares were monitored by transrectal palpation and ultrasonography (Mindray® DP 2200 VET, $5 \mathrm{MHz}$ transrectal transducers and $7.5 \mathrm{MHz}$ frequency) for characterization of uterine edema, follicular growth and ovulation. The synchronization interval was considered the interval between the days of application of the second dose of PGF $2 a$ and the detection of ovulation, obtaining the average of the days for mares that ovulated.

\section{Gynecological evaluation}

By transrectal palpation, uterine tonus was classified subjectively on a scale ranging from 1 for minimal uterine tone (flaccid) to 4 for maximum tone (turgid), according to the criteria used by Hayes et al. (1985).

\section{Ultrasound evaluation}

The ultrasound examination was performed every 48 hours to monitor the follicles that were identified and measured from static images and obtained the mean value for determining the follicular diameters. The total number of follicles was evaluated on days 0, 7 and 14 of the evaluation in which D0 was the first day of evaluation and considering the follicular emergence from the smallest follicle detected with the follicular wave involving 7-11 follicles (Ginther et al., 2001). The classification of the follicles was based on the follicular diameter, being classified as small ( $\leq 15 \mathrm{~mm})$, medium (16 $-30 \mathrm{~mm}$ ) and large ( $\geq 30 \mathrm{~mm}$; Boeta et al., 2006). Mares were considered in estrus when they had $25 \mathrm{~mm}$ follicles (Pierson, 1993) and were exposed to the presence of a stallion to verify sexual receptivity. The daily follicular growth rate was estimated for the dominant follicles (Almeida et al., 2001), obtaining the mean value for RS and DS. The dominant follicle was considered to be that follicle with a diameter $\geq 22.5 \mathrm{~mm}$ (Ginther et al., 2003). For pre-ovulatory follicle, it was considered the one with a diameter of $30 \mathrm{~mm}$ (Valle et al., 2005), with the pre-ovulatory period being the time elapsed between the detection of the pre-ovulatory follicle and the recording of ovulation, when the evaluations ultrasounds have become daily. The ovulation rate was determined by the frequency of ovulations recorded in both periods. After ovulation, the formation of the corpus luteum was monitored with ultrasonographic evaluations taking place at an interval of 48 hours. The interovulatory interval was considered the period between an ovulation and the subsequent ovulation.

The uterine echotexture evaluation was used to estimate the degree of the uterine score, following the Samper and Pycock ranking (Samper and Pycock, 2007), which establishes a degree of edema between 0 and 5, where 0 corresponds to the uterus without edema, 4 with strong edema and 5 with abnormal edema.

\section{Hormonal Assay}

Blood samples collected by jugular vein puncture and stored in $5 \mathrm{~mL}$ heparinized tubes.

The samples were centrifuged at $1500 \times \mathrm{g}$ for 10 minutes, and the plasma was decanted and placed in storage tubes at $-20^{\circ} \mathrm{C}$ (Ginther et al., 2008). Blood sampling started 72 hours after synchronization and occurred on alternate days up to 10 days after ovulation, following the days of ultrasonographic evaluation. 
The levels of progesterone (P4) were determined by the enzyme immunoassay (ELISA) method, according to the procedure recommended by the commercial kit (DRG Progesterone Enzyme Immunoassay Kit, EIA - 1561, DRG - Germany) and performed at the Immunodiagnostic Laboratory of UEMA. The P4 reference solutions used in the trial were: Calibrator 0: S0 ng / mL; S1: $0.3 \mathrm{ng} / \mathrm{mL}$; S2: 1.25 ng / mL, S3: 2.5 ng / mL, S4: 5 ng / mL; S5: 15 ng / mL; S6: 20 ng / mL. The intra-assay coefficient of variation was $5.4 \%$ for $0.62 \mathrm{ng} / \mathrm{mL} ; 6.99 \%$ to $4.67 \mathrm{ng} / \mathrm{mL} ; 6.86 \%$ to $10.80 \mathrm{ng} / \mathrm{mL}$. The inter-assay coefficient of variation was $9.96 \%$ for $0.56 \mathrm{ng} / \mathrm{mL} ; 4.34 \%$ to $4.55 \mathrm{ng} / \mathrm{mL} ; 5.59 \%$ to $10.65 \mathrm{ng} / \mathrm{mL}$. The readings were performed by spectrophotometer (Biotek EL x 800), the Gen5 program Getting Started, Microplate Data Collection and Analysis Software.

\section{Experimental design and statistical analysis}

Data were analyzed by mean, standard deviation, and percentage frequency for each variable. The SAS statistical software (Student Newman Keuls test) was used to determine differences among data on weight, ECC, tonus, synchronization, rainfall, daytime duration, follicular development, and mare hormonal levels between RS and DS for animals before and after ovulation.

Data were normalized by the Cramer-von Mises test to classify follicular diameters and the analyses of treatment interactions, interactions between periods, and its relation to progesterone levels were performed through a multiple-comparison factorial using the TukeyKramer test. The difference in ovulation rate and number of follicles between the RS and DS periods was determined by the Chi-square test using the significance level $P<0.05$.

\section{Ethics statement}

The experiment was conducted at the State University of Maranhão's Experimental Farm Fazenda Escola de São Bento, FESB/UEMA (Lat 1859'S; Long 56³9'W), in year 2015 and in compliance with the Ethics Commission on Animal Research (CEEA - CONCEA / MCT UEMA) approval protocol for this research work (019 / 2015).

\section{Results}

The mares showed no significant difference $(P>0.05)$ for weight, BSC, tonus, and uterine edema during rainy (RS) and dry (DS) periods. Mean values for each trait during RS and DS, respectively were as follows: Weight $236 \mathrm{~kg} \pm 34.72 \mathrm{~kg}$ and $234 \pm 30.78$; BSC $3.60 \pm 0.59$ and $3.63 \pm 0.58$; Tonus $2.22 \pm 0.22$ and $2.24 \pm 0.36$ and Edema $0.39 \pm 0.33$ and $0.51 \pm 0.44$. The mares that had the highest weight and the highest body condition score developed large ovarian follicles. Ovulation was registered in $57.14 \%(8 / 14)$ of the mares in the RS and $25.57 \%$ $(4 / 14)$ in the DS and the frequency of ovulation, no difference $(P>0.05)$ was observed between seasons. (Figure 1).

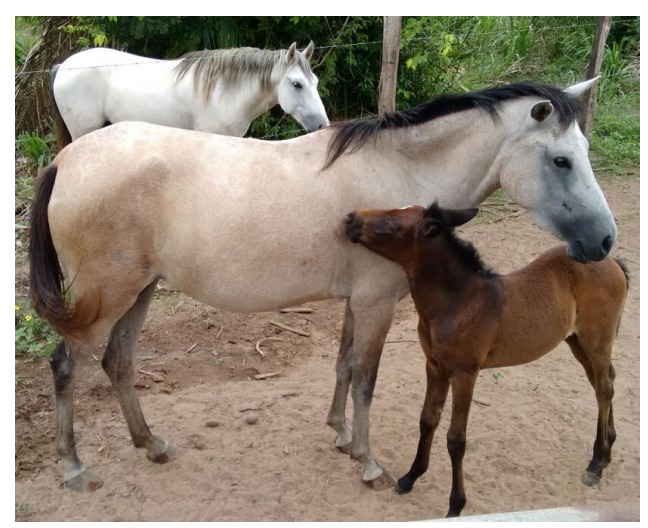

Figure 1. Mare and foal, behind a stalion Baixadeiro. 
As for tonus and edema, changes were observed throughout the estrus, in which ovulating mares showed minimal tonus and a higher degree of edematous close to ovulation (Figure 2).

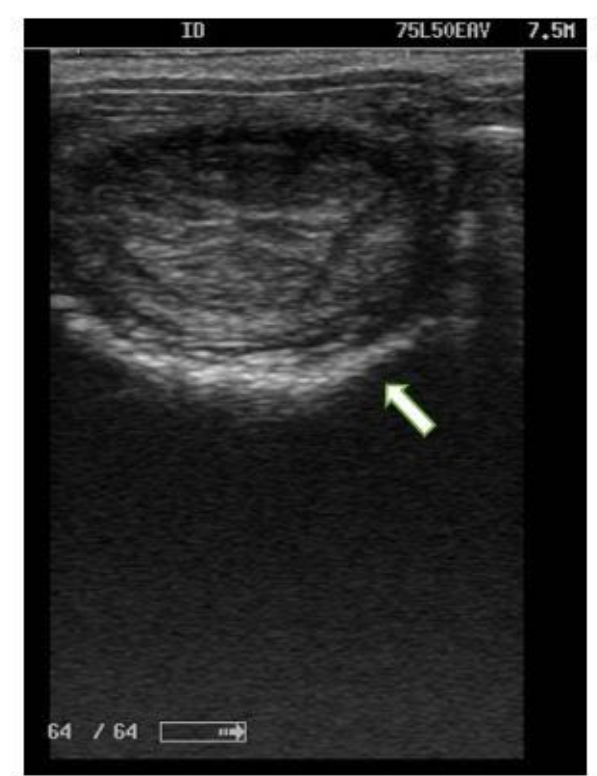

2a. Degree 0: no edema

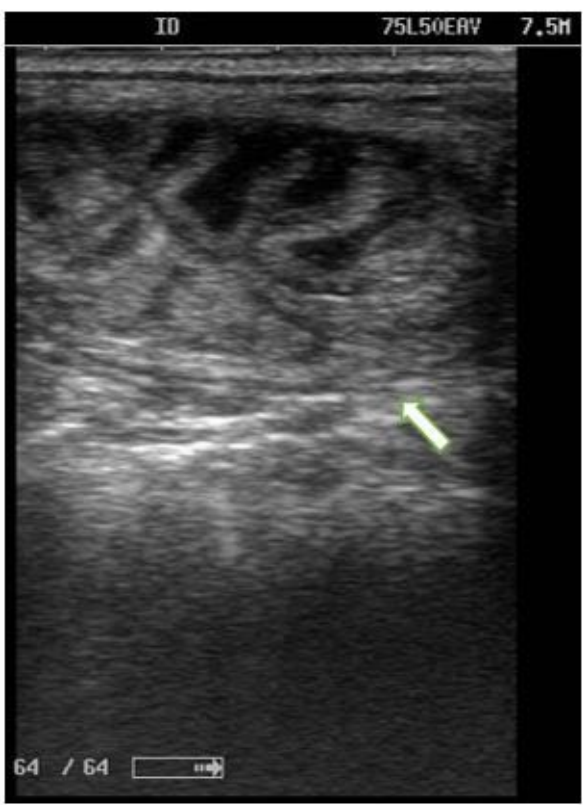

2c. Degree 3: edema 3 (folds)

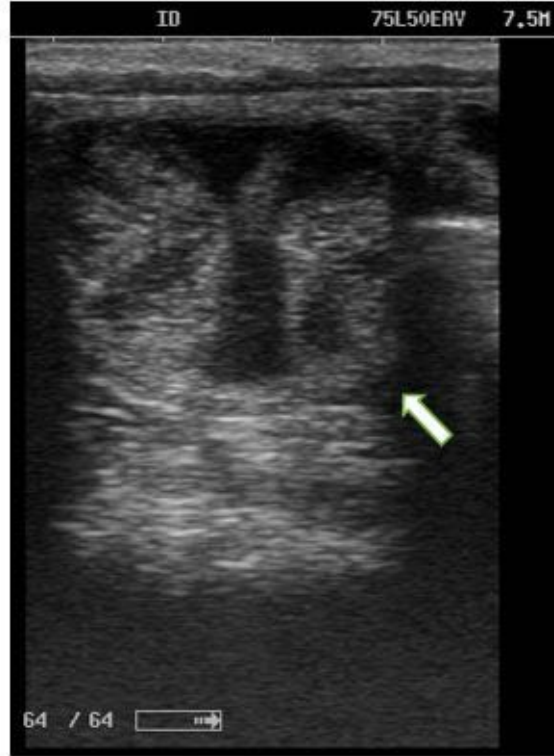

2b. Degree 2: edema 2

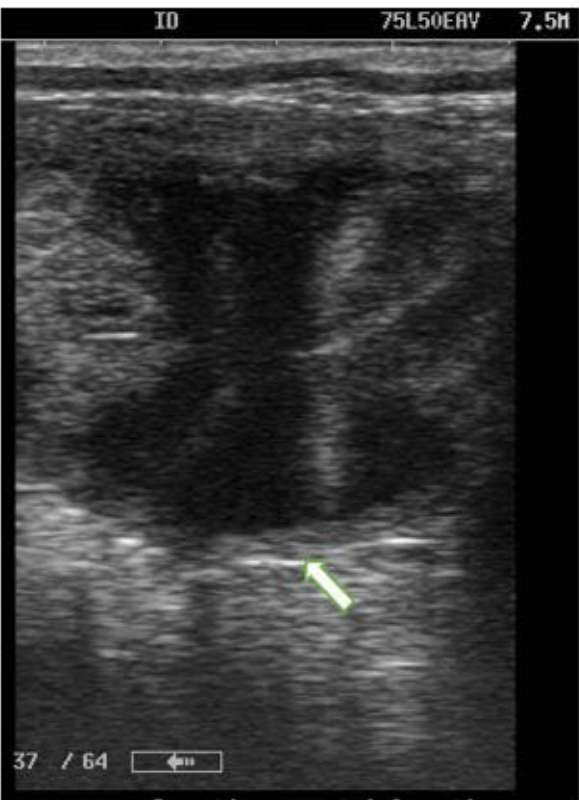

2d. Degree 4: Edema 4 (endometrial folds

and intrauterine fluid)

Figure 2. Degree of uterine edema in the rainy and dry periods ranging from 0 to 4 on the rating scale. Degree 0 = No Edema, Degree 1 = Edema, Degree 2 = Edema 2 (fluid), Degree 3 = Edema 3 (folds), Degree 4 = Edema 4 (endometrial folds and intrauterine fluid).

There was no statistical difference between RS and DS for the total number of follicles between days $0(6.57 \pm 2.63$ and $4.85 \pm 2.13)$, days $7(6.50 \pm 3.28$ and $6.85 \pm 3.62$ and day 14 $(8.00 \pm 2.23$ and $7.28 \pm 3.49)$, these are in agreement with the number of expected follicles during follicular wave emergence and are independent of body condition. The total number of small, medium and large follicles (Figure 3) in mares was different between RS and DS. Larger 
diameters were recorded for medium follicles in RS (RS $22.71 \pm 0.27$ and DS $19.50 \pm 0.43$ ), large follicles in turn had larger diameters in DS (RS $34.45 \pm 0.55$ and $38.44 \pm 1.82$ ), as shown in Table 1.

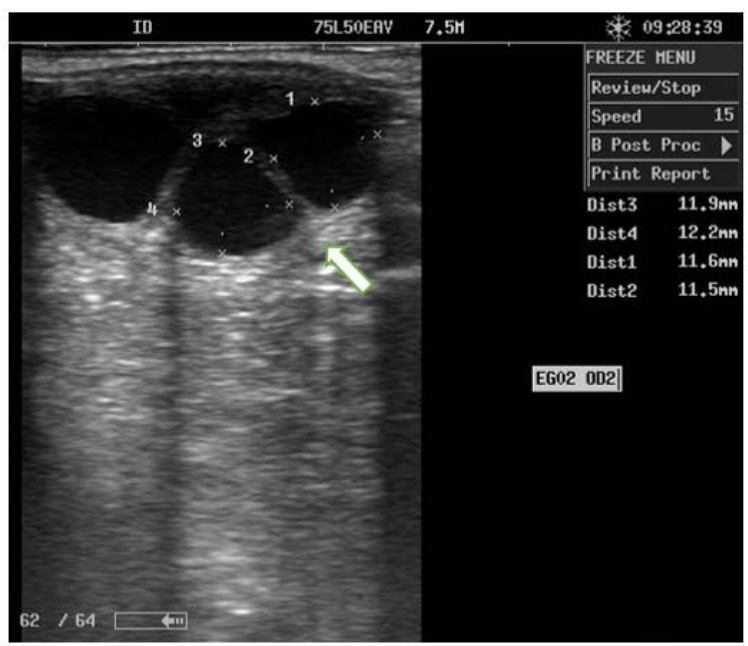

A

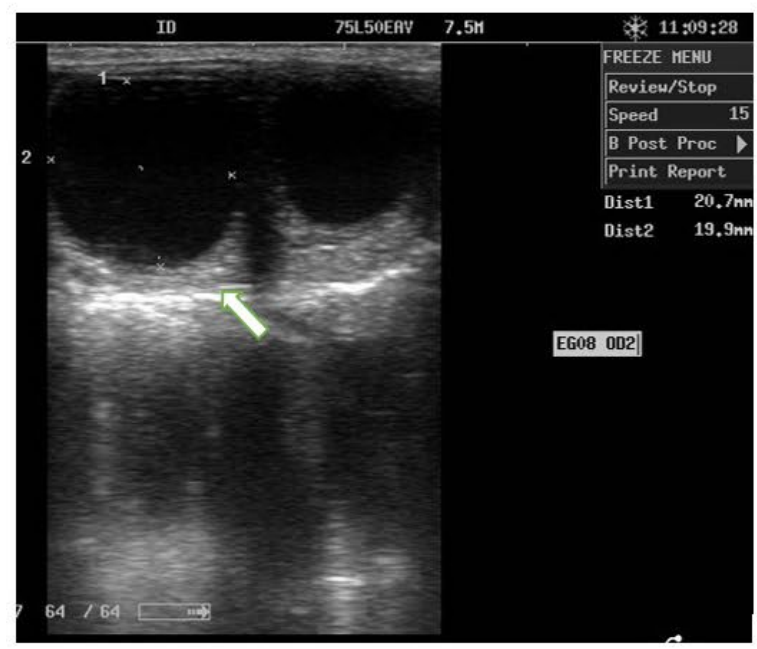

B

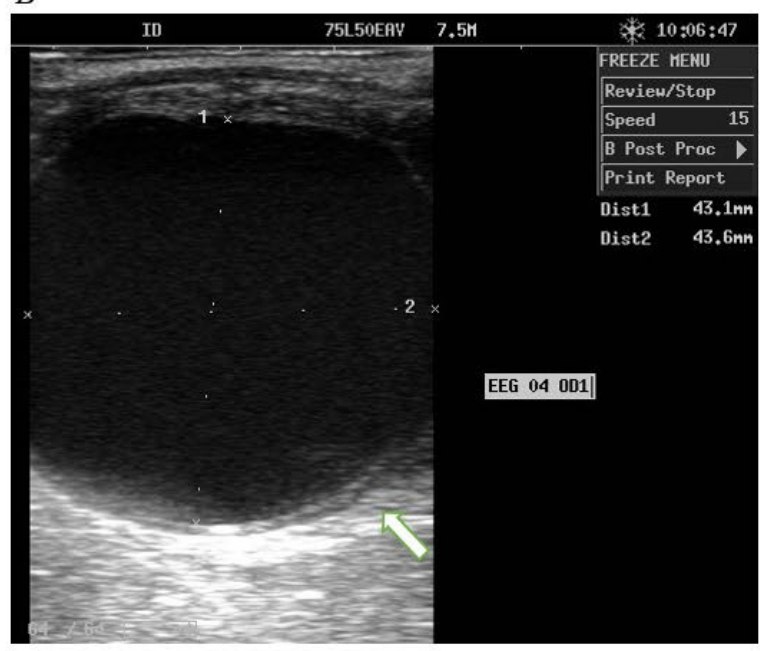

C

Figure 3. Follicular growth in the rainy and dry periods ranging. A: Small follicles $<15 \mathrm{~mm}$, B: Medium follicles: $15-30 \mathrm{~mm}$, C: Large follicles $>30 \mathrm{~mm}$. 
Table 1. Mean and standard deviation of follicle diameter of mares during the 2015 rainy and dry seasons.

\begin{tabular}{|c|c|c|c|c|}
\hline \multirow{2}{*}{$P$ value } & \multirow{2}{*}{ Season } & \multicolumn{3}{|c|}{ Follicle diameter } \\
\hline & & $\leq 15 \mathrm{~mm}$ & $16-30 \mathrm{~mm}$ & $\geq 30 \mathrm{~mm}$ \\
\hline$(P<0.05)$ & Rainy & $10.97 \pm 0.15^{\mathrm{Ca}}$ & $22.71 \pm 0.27^{\mathrm{Ba}}$ & $34.45 \pm 0.55^{\mathrm{Ab}}$ \\
\hline$(P<0.05)$ & Dry & $10.40 \pm 0.21 \mathrm{Ca}$ & $19.50 \pm 0.43^{\mathrm{Bb}}$ & $38.44 \pm 1.82^{\mathrm{Aa}}$ \\
\hline
\end{tabular}

Means with different superscripts $(\mathrm{A}, \mathrm{B})$ within the row, $(\mathrm{a}, \mathrm{b})$ within the column are significant at $P<0.05$.

Regarding the traits of the periovulatory period, no difference $(P>0.05)$ was observed for the synchronization interval (mean $12.25 \pm 5.85 \mathrm{RS}, 15.40 \pm 10.52 \mathrm{DS}$ ), estrus (mean $7.18 \pm 3.02 \mathrm{RS}$, $7.45 \pm 3.05 \mathrm{DS}$ ) and follicular growth rate between seasons (mean $2.34 \pm 0.49 \mathrm{RS}, 1.66 \pm 1.06 \mathrm{DS}$ ).

The analysis of follicular divergence showed no differences between the dominant follicles (RS $21.8 \pm 2.00 \mathrm{~mm} / \mathrm{DS} 21.57 \pm 1.70 \mathrm{~mm}$ ) and subordinate follicles (RS $19.03 \pm 2.45 \mathrm{~mm} /$ DS $17.71 \pm 1.90 \mathrm{~mm}$ ) between seasons.

Differences in the preovulatory follicle diameter ( $P<0.05$ - RS $35.40 \pm 2.37$, DS $39.70 \pm 2.77$ ) were observed during the dry season since mares required longer periods to ovulate during this season. The maximum diameter of the preovulatory follicle was recorded on the day before ovulation and showed differences between rainy and dry periods $(P<0.05-\mathrm{RS} 35.40 \pm 2.37$, DS $39.70 \pm 2.77$ ), in that this difference observed was greater during the dry season, since the mares needed longer periods to ovulate in this season.

Mares showed differences $(P<0.05)$ on the mean levels of P4 between the pre and post ovulatory phases in both seasons (RS and DS), being less than $1 \mathrm{ng} / \mathrm{mL}$ before ovulation and immediately increasing its value. Differences between seasons $(P<0.05)$ were recorded in the post-ovulatory phase, when the higher the ovulation rate, the higher the DS concentration (Table 2).

Table 2. Mean and standard deviation of progesterone levels during the pre- and post-ovulatory phases of mares of the Baixadeiro genetic group during the 2015 rainy and dry seasons.

\begin{tabular}{cccc} 
P value & Season & \multicolumn{2}{c}{$\begin{array}{c}\text { Progesterone levels } \mathbf{( n g} / \mathbf{~} \mathbf{L}) \\
\text { Post ovulatory }\end{array}$} \\
& Rainy & $0.385 \pm 0.689^{\mathrm{Ab}}$ & $13.993 \pm 11.934^{\mathrm{Aa}}$ \\
\hline$(P<0.05)$ & Dry & $0.646 \pm 1.416^{\mathrm{Ab}}$ & $8.045 \pm 6.036^{\mathrm{Ba}}$ \\
\hline
\end{tabular}

Means with different superscripts $(A, B)$ within the row, $(a, b)$ within the column are significant at $P<0.05$.

Regardless of the season, P4 levels differed $(P<0.05)$ between the pre- and post-ovulatory phases. Climate variables differed between seasons, with daily luminosity values peaking in February when there was a difference of 12 minutes $(P<0.05)$. Total rainfall was also higher in February (Table 3), although not different.

Table 3. Mean and standard deviation for daily rainfall precipitation and luminosity during the experimental period.

\begin{tabular}{cccc} 
P value & \multicolumn{2}{c}{ Season } \\
& & Rainy & Dry \\
\hline$(P<0.05)$ & Daily precipitation $^{*}$ & $4.07 \pm 0.77^{\mathrm{A}}$ & $1.10 \pm 2.65^{\mathrm{A}}$ \\
\hline$(P<0.05)$ & Daily luminosity $^{* *}$ & $12.18 \pm 0.02^{\mathrm{A}}$ & $11.98 \pm 0.01^{\mathrm{B}}$ \\
\hline
\end{tabular}

Sources: *NUGEO. **INMET (2015). Means with different superscripts (A, B) within the row, $(a, b)$ within the column are significant at $P<0.05$.

The mares of the Baixadeiro group remained cyclical between seasons (Table 4), thus deconstructing the reproductive seasonality. 
Table 4. Mean and standard deviation of follicular diameters and progesterone levels during the pre- and post-ovulatory phases of mares of the Baixadeiro genetic group during the 2015 rainy and dry seasons.

\begin{tabular}{|c|c|c|c|c|c|c|c|c|c|}
\hline \multirow{3}{*}{$P$ value } & \multirow{3}{*}{ Season } & \multicolumn{8}{|c|}{ FOLLICULAR ACTIVITY } \\
\hline & & \multicolumn{3}{|c|}{ Pre ovulatory } & \multicolumn{3}{|c|}{ Post ovulatory } & \multicolumn{2}{|c|}{ P4 levels ( $\mathrm{ng} / \mathrm{mL}$ ) } \\
\hline & & $<15 \mathrm{~mm}$ & $16-30 \mathrm{~mm}$ & $>30 \mathrm{~mm}$ & $<15 \mathrm{~mm}$ & $16-30 \mathrm{~mm}$ & $>30 \mathrm{~mm}$ & Pre & Post \\
\hline$P<0.05$ & Rainy & $10.12 \pm 4.31^{c}$ & $19.16 \pm 2.84^{\mathrm{Ba}}$ & $35.35 \pm 3.10^{\mathrm{Aa}}$ & $8.60 \pm 2.97^{\mathrm{Ca}}$ & $19.87 \pm 3.33$ ва & $32.87 \pm 1.85^{\mathrm{Aa}}$ & $0.29 \pm 0.54 \mathrm{Ed}$ & $13.99 \pm 11.93^{\mathrm{Dd}}$ \\
\hline$P<0.05$ & Dry & $10.66 \pm 2.68^{c}$ & $21.21 \pm 3.61 \mathrm{Ba}$ & $39.60 \pm 5.30^{\mathrm{Ab}}$ & $8.08 \pm 2.54^{\mathrm{Ca}}$ & $18.24 \pm 3.07^{\mathrm{Ba}}$ & & $0.64 \pm 1.40 \mathrm{Ed}$ & $8.04 \pm 6.07^{\mathrm{De}}$ \\
\hline
\end{tabular}

\section{Discussion}

Horse reproduction tends to be seasonal (Nagy et al., 2000). The main adjusting factor in their original temperate ranges is photoperiod variation. However, it is absent in equatorial because, in low tropical latitudes, day length variation is minimal, and rainfall variation makes the seasonal cycle less predictable (Boeta et al., 2006; Ramírez et al., 2010; Nascimento, 2014; Ogutu et al., 2015; Carranza et al., 2017). Hence, factors affecting mares' conditions and foaling success may influence the dates of reproduction in these areas.

Changes in tonicity during the reproductive cycle in mares have already been described (Hayes and Ginther, 1986; Cuervo-Arango et al., 2020), as the luteal phase approaches (Griffin et al., 1992; Alonso et al., 2019), with no change occurring during the anovulatory seasonality (Hayes and Ginther, 1986). Also, changes in uterine consistency and texture have been shown to occur gradually throughout estrus (Hayes et al., 1985), characterizing the estrus edema (Moura, 2012).

Our results have not evidence significant differences for weight, BSC, tonus, and uterine edema during rainy (RS) and dry (DS) periods, but mares showing ovarian activity were those with higher weight and body condition. One possible explanation for results evidenced here is that mares increase body condition after the forage grows during the rainy season and then start breeding (i.e., increase their pregnancy rate and hence foaling occurs close to this season next year). Mares largely rely on stored reserves and need to be in good condition before starting reproduction (Houston et al., 2007). However, mares with low body condition may produce fewer follicles before their first ovulation during the reproductive season (Gastal et al., 2004).

For estrous synchronization and induction, PGF $2 a$ can be applied at any stage of the estrous cycle in two doses (Irvine, 1993). The results for synchronization intervals were higher than those reported in the literature because mares synchronized with PGF $2 a$ ovulate between 8 - 10 days after induction (Samper, 2008), which may vary between breeds (Griffin et al., 1992; CuervoArango et al., 2015), depending on the dosage administered (Cuervo-Arango et al., 2015) and follicle size at the time of administration (Samper, 2008; Bender et al., 2014).

The estrus period lasted as expected for the species, which may comprise an interval between 2 to 12 days, typically longer at the beginning of the reproductive season (Blanchard et al., 2003). These results are in agreement with those reported for marshy mares (Zúccari et al., 2002), crossbred mares (Valle et al., 2005), Purebred Arabian and Arabian Crossbred mares (Romano et al., 1998), clearly showing the variation between races of different regions, management, and environmental conditions.

The average follicle size of ovulating mares ranges from 40 to $45 \mathrm{~mm}$ (Blanchard et al., 2003) and can vary among breeds. In Thoroughbred mares, follicle size can range between $39.95 \pm 4.84$ $\mathrm{mm}$ (Morel et al., 2010), for the Colombian Paso Fino mares $41.34 \pm 2.14 \mathrm{~mm}$ (Ramírez et al., 2010), with seasonal variations ranging between $48.7 \pm 9.7 \mathrm{~mm}$ and $42.5 \pm 9.1 \mathrm{~mm}$ (Nascimento, 2014) and for Pantaneira mares $49.5 \pm 2.0 \mathrm{~mm}$ (Zúccari et al., 2002). For parous mares, mean follicle size is $51.7 \mathrm{~mm}$, and $49.3 \mathrm{~mm}$ for empty mares of the Campolina Breed (Zúccari, 1990) and $34.21 \pm 0.37$ $\mathrm{mm}$ Mangalarga Marchador mares (Rodrigues et al., 2011). The range of preovulatory follicle size values emphasizes its relation to season, breed, and mare type (Ginther, 1995).

In the luteal phase, the maximum peripheral concentration of $\mathrm{P} 4$ is variable among mares (Carnevale et al., 1997), due to the secretory capacity of corpus luteum (CL) or the progesterone catabolism rate, since the factors that determine its level in cyclic mares are the cycling date 
and several ovulations (Nagy et al., 2004). Mature CL can produce, on average, 8 - $10 \mathrm{ng} / \mathrm{mL}$ until it undergoes luteolysis (Arruda et al., 2001) or produces values similar (Vivo et al., 1986) to those found in this study.

Concerning the follicular activity during the pre- and post-ovulatory phases, P4 levels were lower than $1 \mathrm{ng} / \mathrm{mL}$ in the presence of large and medium-sized follicles, with levels increasing after ovulation. This is because although a pool of small follicles begins to increase until ovulation, its number does not change in the ovaries throughout the estrous cycle, and what happens is that some follicles change of category (Pierson and Ginther, 1987). In the follicular phase, minimum progesterone levels can be detected, accompanied by an increase in follicular diameter during estrus and ovulation (Ginther et al., 2007). This is because changes in plasma P4 levels occur immediately after ovulation (Ginther et al., 2008), reaching $3 \mathrm{ng} / \mathrm{mL}$ (Ginther and Santos, 2015), increasing to D6 after which they plateau (Arruda et al., 2001). Similar results were reported for Arabian mares (Abo-El maaty and El-Shahat, 2012), in which the P4 serum levels were significantly higher in the luteal phase of the estrous cycle.

For these animals, weight can be considered the main factor interfering with follicular development and the interval between reproductive seasons, as BSC is associated with an increase in reproductive activity (Nagy et al., 2000; Lopes et al., 2017), as recorded for the animals from this work. Rainfall influenced the ovarian activity since most ovulation occurred during the rainy season, when pasture growth was exuberant, which promoted forage intake resulting in higher weight gain and BSC levels. The dry season at the Baixada Maranhense region sharply decreases forage availability, leading to the loss of nutritional quality, and consequently, live weight loss in equines (Santos, 1997; Barros et al., 2019). Since animals in tropical environments do not observe reproductive seasonality, when subjected to nutritional stress, mares tend to decrease their reproductive activity (Ramírez et al., 2010).

\section{Conclusion}

Mares from the Baixadeiro genetic group did not show reproductive seasonality in conditions such as their natural environment, although there was a difference in luminosity between the rainy and dry seasons. During the pre- and post-ovulatory phases, progesterone concentrations were within the expected levels for this species, regardless of the season. The treatment with two doses of PGF $2 a$ was effective in synchronizing the mares, promoting the return of estrus in the dry and rainy periods. Thus, mares exhibited a cyclical behavior throughout the year, exhibiting reproductive activity under conditions of adequate weight and body condition score.

\section{References}

Abo-El maaty AM, El-Shahat $\mathrm{KH}$. Hormonal and biochemical serum assay in relation to the estrous cycle and follicular growth in Arabian mare. As Pac J of Reprod, 2012;1(2):105-110.

Almeida HB, Viana WG, Arruda RP, Oliveira CA. Sincronização de estro e dinâmica folicular de éguas Crioulas submetidas a tratamentos com norgestomet, acetato de melengestrol e altrenogest. Braz J Vet Res Anim Sci. 2001;38(6):267-72. http://dx.doi.org/10.1590/S1413-95962001000600004.

Alonso MA, Silva LA, Affonso FJ, Lemes KM, Celeghini ECC, Lançoni R, Carvalho HF, Arruda RP. Effect of hCG application at different moments of the estrous cycle on corpus luteum and uterine vascularization and serum progesterone concentration in mares. Anim Reprod. 2019;16(2):317-27. http://dx.doi.org/10.21451/1984-3143-AR2018-0103. PMid:33224293.

Arruda RPD, Visintin JA, Fleury JJ, Garcia AR, Madureira EH, Celeghini ECC, Neves Neto JR. Existem relações entre tamanho e morfoecogenicidade do corpo lúteo detectados pelo ultrassom e os teores de progesterona plasmática em receptoras de embriões equinos? Braz J Vet Res Anim Sci. 2001;38(5):233-9. http://dx.doi.org/10.1590/S1413-95962001000500007.

Barros BS, Hunka MM, Souza AL, Silva JFL, Coelho CS, Manso HECC, Manso Filho HC. Vitamin D concentrations and biological biomarkers of lactating mares and foals in the dry season. Pferdeheilkunde. 2019;35(4):344-9. http://dx.doi.org/10.21836/PEM20190406.

Bender ESC, Sampaio BFB, Nogueira BG, Costa-e-Silva EV, Zúccari CESN. Condição corporal e atividade reprodutiva de éguas. Arch Zootec. 2014;63(241):55-67. http://dx.doi.org/10.21071/az.v63i241.590. 
Blanchard TL, Varner DD, Schumacher J. Reproductive Physiology of the Nonpregnant Mare. In: Fathman EM, Merchant T, editors. Manual of equine reproduction. St Louis, Missouri: Mosby; 2003. p.9-15.

Boeta M, Porras A, Zarco LA, Aguirre-Hernández R. Ovarian activity of the mare during winter and spring at a latitude of $19^{\circ} 21^{\prime}$ north. J Equine Vet Sci. 2006;26(2):55-8. http://dx.doi.org/10.1016/j.jevs.2005.12.003.

Carnevale EM, Hermenet MJ, Ginther OJ. Age and pasture effects on vernal transition in mares. Theriogenology. 1997;47(5):1009-18. http://dx.doi.org/10.1016/S0093-691X(97)00058-7. PMid:16728051.

Carranza J, Yoong WA, Mateos C, Caño Vergara B, Gómez CL, Macías V. Reproductive phenology of Creole horses in Ecuador in the absence of photoperiod variation: the effects of forage availability and flooding affecting body condition of mares. Anim Sci J. 2017;88(12):2063-70. http://dx.doi.org/10.1111/asj.12818. PMid:28748628.

Cuervo-Arango J, Martín-Peláez MS, Claes AN. A practical guide to estimate the age of the early CL by ultrasonography in mares examined for the first time to be used as recipients in a commercial embryo transfer program. Theriogenology. 2020;153(1):48-53. http://dx.doi.org/10.1016/j.theriogenology.2020.05.003. PMid:32417611.

Cuervo-Arango J, Mateu-Sánchez S, Aguilar J, Nielsen JM, Etcharren V, Vettorazzi ML, Newcombe JR. The effect of the interval from PGF treatment to ovulation on embryo recovery and pregnancy rate in the mare. Theriogenology. 2015;83(8):1272-8. http://dx.doi.org/10.1016/j.theriogenology.2015.01.010. PMid:25666044.

Faria DR, Gradela A. Hormonioterapia aplicada à ginecologia equina. Rev Bras Reprod Anim. 2010;34(2):114122. Available from: http://www.cbra.org.br/pages/publicacoes/rbra/v34n2/p114-122.pdf.

Ferreira-Dias G, Claudino F, Carvalho H, Agrícola R, Alpoim-Moreira J, Silva JR. Seasonal reproduction in the mare: possible role of plasma leptin, body weight and immune status. Domest Anim Endocrinol. 2005;29(1):203-13. http://dx.doi.org/10.1016/j.domaniend.2005.02.006. PMid:15927774.

Gastal MO, Gastal EL, Spinelli V, Ginther OJ. Relationships between body condition and follicle development in mares. Anim Reprod. 2004 [cited 2015 Sept 17];1(1):115-21. Available from: https://animal-reproduction.org/article/5b5a608cf7783717068b4814/pdf/animreprod-1-1-115.pdf

Gazolla AG, Serra OR, Lima FC. Pelagens do cavalo da raça baixadeira. In: 46 Reunião Anual Sociedade Brasileira Zootecnia; 2009 jul 14-17, Maringá, PR, Brasil. Maringá: SBZ; 2009. p.1-3.

Ginther OJ, Beg MA, Bergfelt DR, Donadeu FX, Kot K. Follicle selection in monovular species. Biol Reprod. 2001;65(3):638-47. http://dx.doi.org/10.1095/biolreprod65.3.638. PMid:11514323.

Ginther OJ, Beg MA, Donadeu FX, Bergfelt DR. Mechanism of follicle deviation in monovular farm species. Anim Reprod Sci. 2003;78(3-4):239-57. http://dx.doi.org/10.1016/S0378-4320(03)00093-9. PMid:12818647.

Ginther OJ, Gastal EL, Rodrigues BL, Gastal MO, Beg MA. Follicle diameters and hormones concentrations in the development of single versus double ovulation in mares. Theriogenology. 2008;69(5):583-90. http://dx.doi.org/10.1016/j.theriogenology.2007.11.004. PMid:18242675.

Ginther OJ, Santos VG. Natural rescue and resurgence of the equine corpus luteum. J. Eq Vet Scie. 2015;35(1):1-6. http://dx.doi.org/10.1016/j.jevs.2014.10.004.

Ginther OJ, Utt MD, Beg MA. Follicle deviation and diurnal variation in circulating hormone concentrations in mares. Anim Reprod Sci. 2007;100(1-2):197-203. http://dx.doi.org/10.1016/j.anireprosci.2006.08.025. PMid:17000062.

Ginther OJ. Folliculogenesis during the transitional period and early ovulatory season in mares. J Reprod Fertil. 1990;90(1):311-20. http://dx.doi.org/10.1530/jrf.0.0900311. PMid:2231551.

Ginther OJ. Reproductive biology of the mare: basic and applied aspects. 2nd ed. Cross Plains: Equiservices Publishing; 1995. p. 10-20.

Griffin PG, Hermenet MJ, Ginther OJ. A transient increase in uterine tone during early diestrus in mares. Theriogenology. 1992;37(6):1185-90. http://dx.doi.org/10.1016/0093-691X(92)90174-P.

Haetinger C, Torres A, Brum C, Nogueira CEW. Uso comparativo de progesterona sintética-P4 e PGF2-a na sincronização de cio em éguas da raça crioula. In: XVII Congresso de Iniciação científica e X Encontro de Pós-Graduaçã; 2000 Nov 11-14; Pelotas, RS. Pelotas: Universidade Federal de Pelotas; 2008.

Hayes KEN, Ginther OJ. Role of progesterone and estrogen in development of uterine tone in mares. Theriogenology. 1986;25(4):581-90. http://dx.doi.org/10.1016/0093-691X(86)90142-1. PMid:16726149.

Hayes KEN, Pierson RA, Scraba ST, Ginther OJ. Effects of estrous cycle and season on ultrasonic uterine anatomy in mares. Theriogenology. 1985;24(4):465-77. http://dx.doi.org/10.1016/0093691X(85)90053-6. PMid:16726101. 
Henneke DR, Potter GD, Kreider JL, Yeates BF. Relationship between condition score, physical measurements and body fat percentage in mares. Equine Vet J. 1983;15(4):371-2. http://dx.doi.org/10.1111/j.2042-3306.1983.tb01826.x. PMid:6641685.

Houston Al, Stephens PA, Boyd IL, Harding KC, McNamara JM. Capital or income breeding? A theoretical model of female reproductive strategies. Behavioral Ecology. 2007;1(8):241-250.

INMET - Instituto Nacional de Meteorologia [homepage on the Internet]. Brasília: Ministério da Agricultura, Pecuária e Abastecimento; 2015. [cited 2015 Sept 17]. Available from: http://www.inmet.gov.br.

Irvine CHG. Prostaglandins. In: Mckinnon AO, Voss JL, editors. Equine reproduction. Philadelphia: Lea \& Febiger. 1993. p. 319-324

Klein SL, Nelson RJ. Influence of social factors on immune function and reproduction. Rev Reprod. 1999;4(3):168-78. http://dx.doi.org/10.1530/ror.0.0040168. PMid:10521154.

Lopes KRF, Lima GL, Bezerra LGP, Barreto-Junior RA, Oliveira MF, Silva AR. Characterization of the ovarian preantral follicle populations and its correlation with age and nutritional status in Brazilian Northeastern donkeys (Equus assinus). Anim Reprod Sci. 2017;187:193-202. http://dx.doi.org/10.1016/j.anireprosci.2017.11.007. PMid:29126831.

McKinnon AO, Voss JL. Equine reproduction. 5th ed. Philadelphia: Lea \& Febiger, 1992. p. 52.

Morel MCGD, Newcombe JR, Hayward K. Factors affecting pre-ovulatory follicle diameter in the mare: the effect of mare age, season and presence of other ovulatory follicles (multiple ovulation). Theriogenology. 2010;74(7):1241-7. http://dx.doi.org/10.1016/j.theriogenology.2010.05.027. PMid:20615543.

Moura JCA. Diagnóstico por imagem na reprodução equina "controle do útero". Ciênc Anim. 2012;22(1):161-70.

Nagy P, Guillaume D, Daels P. Seasonality in mares. Anim Reprod Sci. 2000;60-61:245-62. http://dx.doi.org/10.1016/S0378-4320(00)00133-0. PMid:10844199.

Nagy P, Huszenicza G, Reiczigel J, Juhasz J, Kulcsar M, Abavary K, Guillaume D. Factors affecting plasma progesterone concentration and the retrospective determination of time of ovulation in cyclic mares. Theriogenology. 2004;61(2-3):203-14. http://dx.doi.org/10.1016/S0093-691X(03)00211-5. PMid:14662122.

Nascimento JN. Caracterização do ciclo estral de éguas da raça Pantaneiro e Campeiro no Planalto Central [dissertation]. Brasília: Universidade de Brasília; 2014. Portuguese.

Ogutu JO, Owen-Smith N, Piepho HP, Dublin HT. How rainfall variation influences reproductive patterns of African savanna ungulates in an equatorial region where photoperiod variation is absent. PLoS One. 2015;10(8):e0133744. http://dx.doi.org/10.1371/journal.pone.0133744. PMid:26295154.

Pierson RA, Ginther OJ. Follicular population dynamics during the estrous cycle of the mare. Anim Reprod Sci. 1987;14(3):219-31. http://dx.doi.org/10.1016/0378-4320(87)90085-6.

Pierson RA. Foliculogenesis and ovulation. In: Mckinnon AO, Voss JL, editors. Equine reproduction. Malvern: Lea \& Febiger. 1993. p.161-171.

Ramírez G, Gutiérrez C, Ramos M. Dinámica folicular en yeguas paso fino colombiano medido por ultrasonografía en la Sabana de Bogotá. Ver Med Vet. 2010;19(19):21-35. http://dx.doi.org/10.19052/mv.781.

Rodrigues PG, Raymundo MC, Souza JC, Miranda CMG, Rezende ASC. Gordura corporal e eficiência reprodutiva em éguas doadoras de embrião Mangalarga Marchador. Cienc Agrotec. 2011;35(5):10028. http://dx.doi.org/10.1590/S1413-70542011000500019.

Romano MA, Mucciolo RG, Silva AEDF. Biologia reprodutiva de éguas: estudo do ciclo estral e momento da ovulação. Braz J Vet Res Anim Sci. 1998;35(1):23-8. http://dx.doi.org/10.1590/S1413-95961998000100004.

Samper JC, Pycock JF. The normal uterus in estrus. In: Rudolph P, Gower J, editors. Current therapy in equine reproduction, St Louis, Missouri: Saunders-Elsevier; 2007. p.32-35. http://dx.doi.org/10.1016/B978-0-7216-0252-3.50009-6.

Samper JC. Induction of estrus and ovulation: why some mares respond and others do not. Theriogenology. 2008;70(3):445-7. http://dx.doi.org/10.1016/j.theriogenology.2008.04.040. PMid:18554709.

Santos SA. Recomendações sobre manejo nutricional para equinos criados em pastagens nativas no Pantanal. Corumbá: EMBRAPA-CPAP; 1997. P. 22-63.

Serra OR. Condições de manejo, preservação e caracterização fenotípica do grupamento genético equino "Baixadeiro" [dissertation]. São Luís: Universidade Estadual do Maranhão; 2004. Portuguese.

Stabenfeldt HG, Edqvist EL. Processos reprodutivos na fêmea. In: Swenson JM, Reece OW, editors. Fisiologia dos animais domésticos. 11th ed. Rio de Janeiro: Roca, 1996, p. 615 
Valle GR, Silva Filho JM, Palhares MS. Características cíclicas e ovulatórias de éguas mestiças em Minas Gerais, Brasil. Arq Cien Vet Zool. 2005 [cited 2015 Sept 17];8(2):155-63. Available from: https://revistas.unipar.br/index.php/veterinaria/article/view/53

Vivo R, Santisteban R, Tovar P, Castejon MF. Valores de progesterona en plasma de yeguas españolas y arabes durante el ciclo reproductor. Arch Zootec. 1986 [cited 2015 Sept 17];131:59-67. Available from: https://www.researchgate.net/publication/43650302_Valores_de_progesterona_en_plasma_de_yeguas_es panolas_y_arabes_durante_el_ciclo_reproductor

Zúccari CESN, Nunes DB, Corrêa Filho RAC. Eficiência reprodutiva de éguas da raça Pantaneira durante as estações de monta 1995/2000. Arch Zootec. 2002[cited 2015 Sept 17];51:139-48. Available from: https://www.redalyc.org/articulo.oa?id=49519417

Zúccari CESN. Eficiência reprodutiva e dinâmica folicular de acordo com a condição corporal de éguas da raça Campolina [dissertation]. Belo Horizonte: Universidade Federal de Minas Gerais; 1990. Portuguese.

\section{Author contributions}

LCR: Writing - original draft, Writing - review \& editing, Methodology, Conceptualization, Data curation, Formal analysis; ECSD: Methodology; RSM: Methodology; CJRMR: Methodology; FLCP: Methodology; LBOC: Methodology; ARAA: Writing - review \& editing; FJMJ: Data curation, Formal analysis; FAS: Conceptualization; RMC: Conceptualization, Funding acquisition, Supervision. 